\title{
AS LEIS DO CÁRCERE: os internos do Centro de Atendimento Juvenil Especializado - Caje
}

\section{Bruna Papaiz Gatti}

Curso: Mestrado em Sociologia

Data de defesa da dissertação: 6 de abril de 2005

Orientadora: Prof $^{a}$ Dr $^{a}$ Maria Salete Kern Machado

\section{Resumo}

A dissertação discute o tema da violência com enfoque nos adolescentes reclusos no Centro de Atendimento Juvenil Especializado (Caje) e tem como objetivo compreender como se dão as relações entre os internos e analisar as representações que os internos fazem de suas relações sociais dentro e fora da instituição.

Para melhor aprofundamento da temática, foi feita uma discussão conceitual sobre o tema e uma análise junto aos internos da instituição em questão por meio de observações in loco, aplicação de questionários, sociometria e entrevistas.

O estudo permitiu elaborar algumas considerações acerca do cotidiano e das regras estabelecidas dentro da instituição, contribuindo para um melhor entendimento da questão do adolescente em conflito com a lei.

Palavras-chave: adolescentes em conflito com a lei, Caje, gangues, liderança, poder, relações sociais, violência. 